\title{
ASSAY OF THE HEAT-LABILE ENTEROTOXIN OF ESCHERICHIA COLI IN INFANT RABBITS
}

\author{
M. N. Burgess*, C. M. Cowley*, J. Melling†, N. A. Mullan* \\ AND P. M. NEWSOME* \\ * Beecham Pharmaceuticals Research Division, Nutritional Research Centre, Walton Oaks, \\ Dorking Road, Tadworth, Surrey KT20 7NT, and † Microbiological Research Establishment, \\ Porton, Salisbury, Wiltshire SP4 OJQ
}

STRAINS of Escherichia coli enteropathogenic for swine have been shown to secrete enterotoxins in vitro (Smith and Halls, 1967b; Gyles and Barnum, 1969). These enterotoxins cause accumulation of fluid when they are introduced into ligated intestinal loops prepared in rabbits or pigs (Smith and Halls, $1967 a$ ). The strains of $E$. coli involved are believed to produce two different types of enterotoxin, namely a heat-labile non-dialysable immunogenic toxin (LT) and a heat-stable dialysable toxin (ST).

The use of infant rabbits for the detection of LT has been reported by Kutas, Vetési and Semjen (1974). The present paper described the response of infant rabbits to LT in greater detail, and the evaluation of them as small-animal models for the detection of LT.

The quantity of LT required for assessment of the infant-rabbit model necessitated a large-scale fermentation, and during the course of this work, it was reported that fermentation of strains of $E$. coli in the presence of lincomycin (Levner, Wiener and Rubin, 1977) or mitomycin C (Isaacson and Moon, 1975 ) increased LT synthesis. Hence, it was decided to investigate the effect of these agents on the yield of LT from E. coli strain P307, and these results are also reported here. The preliminary assessment of increase in yield of LT was determined in rabbit ligated-intestinal loops.

\section{MATERIALS AND METHODS}

Organisms. E. coli strain P307 (08: K87: K88a, b) was obtained from Dr H. Williams Smith (Houghton Poultry Research Station, Houghton, Huntingdonshire). It produced LT and ST. Five substrains resistant to lincomycin $300 \mu \mathrm{g} / \mathrm{ml}$ were obtained by sequential transfer of liquid cultures into media containing increasing concentrations of lincomycin, followed by purification of resistant clones as reported by Levner et al. (1977). The $\operatorname{Lin}^{\mathrm{r}}$ phenotype was stable in the absence of the drug.

Culture media. Large-scale growth of strain P307 was produced on syncase medium (Finkelstein, Norris and Dutta, 1964) modified by the substitution of glucose for sucrose and by the addition of yeast extract $0 \cdot 6 \%(\mathrm{w} / \mathrm{v})$.

The lincomycin-resistant strains were grown on the modified casamino acids and yeast extract medium described by Evans, Evans and Gorbach (1973b) in the presence and absence of linomycin $250 \mu \mathrm{g} / \mathrm{ml}$.

Received 13 Nov. 1978; accepted 29 Nov. 1978. 
Fermentation details. Five freeze-dried cultures of strain P307 were resuspended in five 200 -ml volumes of modified syncase medium in 1-litre Erlenmeyer flasks. After incubation for $18 \mathrm{~h}$ at $37^{\circ} \mathrm{C}$ with shaking ( 200 r.p.m.) in a Gallenkamp Rotary Incubator (Gallenkamp, London), a $5 \%(\mathrm{v} / \mathrm{v})$ inoculum was used to seed 20 litres of modified syncase medium in a 20 -litre bottle. After incubation for $24 \mathrm{~h}$ at $37^{\circ} \mathrm{C}$ with aeration (6 litres/min.) and stirring (250 r.p.m.), this culture was used to inoculate $\mathbf{4 0 0}$ litres of medium in a fermenter as described by Melling and Scott (1972). After incubation for $24 \mathrm{~h}$ at $37^{\circ} \mathrm{C}$ with aeration (120 litres/min.) and stirring (250 r.p.m.), phenol was added to a final concentration of $0.5 \%(\mathrm{w} / \mathrm{v})$ and the culture held at $37^{\circ} \mathrm{C}$ for $30 \mathrm{~min}$. The culture was then centrifuged in a De Laval centrifuge at maximum speed of approximately 8000 r.p.m. (Melling and Phillips, 1975). Twenty litres of the supernatant fluid were harvested for future processing whilst the cell paste was washed with 100 litres of sterile phosphate-buffered saline (PBS; Oxoid, Basingstoke, Hampshire) to remove any residual ST, and was re-centrifuged. The cell paste was stored at $-20^{\circ} \mathrm{C}$.

The effects of lincomycin and of mitomycin C (MTC) were investigated by means of small-scale fermentations as follows. A $10-\mathrm{ml}$ volume of peptone water was inoculated with strain P307 from a Dorset's Egg Slope (Oxoid) and incubated for $18 \mathrm{~h}$ at $37^{\circ} \mathrm{C} ; 1 \mathrm{ml}$ of this culture was added to $100 \mathrm{ml}$ of medium in a $500-\mathrm{ml}$ Erlenmeyer flask and incubated for $48 \mathrm{~h}$ at $37^{\circ} \mathrm{C}$ with shaking ( 200 r.p.m.). Phenol was then added to a final concentration of $0.5 \%(\mathrm{w} / \mathrm{v})$ and the culture left for $30 \mathrm{~min}$. at $37^{\circ} \mathrm{C}$. After centrifugation $(28000 \mathrm{~g})$ for $30 \mathrm{~min}$. at $4^{\circ} \mathrm{C}$, the cell pellet was washed with $50 \mathrm{ml}$ of sterile PBS to remove any residual ST, and re-centrifuged. The cell paste was stored at $-20^{\circ} \mathrm{C}$. The five lincomycin-resistant substrains and the parent strain P307 were grown in the absence and presence of lincomycin. The effect of MTC was investigated by the addition of MTC (final concentration $0.5 \mu \mathrm{g} / \mathrm{ml}$ ) to a syncase-glucose yeast-extract culture seeded $2 \mathrm{~h}$ earlier. Processing was then as above.

Cell-lysate production. Unless otherwise stated, cell lysates were prepared by ultrasonic disintegration of a $5 \%(\mathrm{w} / \mathrm{v})$ wet weight (approximately a $1.2 \% \mathrm{w} / \mathrm{v}$ dry weight) suspension of cells in sterile PBS. The cell suspensions were disintegrated for $15 \mathrm{~min}$. in 100-ml volumes with an MSE Ultrasonicator (MSE, Crawley, Sussex) at maximal power ( 7 microns peak to peak). An ice bath was used to cool the cell suspension during disintegration. The cellular debris was then removed by centrifugation $\left(28000 \mathrm{~g}\right.$ ) for $30 \mathrm{~min}$. at $4^{\circ} \mathrm{C}$. The supernatant fluid was decanted, sterilised by filtration through $0.45-\mu \mathrm{m}$ Millipore filters (Millipore, London), and stored at $-20^{\circ} \mathrm{C}$.

Extracellular-LT production. The 20 litres of cell-free P307 culture supernate were concenof 50000 ; this was achieved by means of an Amicon CH3 Concentrator (Amicon, High Wycombe, Bucks.). The ultrafiltrate was stored whilst the retentate was washed with a 10 -fold excess of deionised water, freeze dried and held at $-20^{\circ} \mathrm{C}$. The ultrafiltrate and washing were processed as above by means of a hollow fibre membrane with a m.w. exclusion limit of 10000 ; the resulting freeze-dried retentate was reconstituted in $200 \mathrm{ml}$ of PBS, sterilised by filtration through a $0.22-\mu \mathrm{m}$ Millipore filter, and held at $-20^{\circ} \mathrm{C}$. The resulting ultrafiltrate was processed once again, this time by means of a hollow fibre membrane with a m.w. exclusion limit of 5000 ; the ultrafiltrate produced, containing ST, was discarded.

Chemicals. Crude cholera enterotoxin was obtained from Wyeth Laboratories, lincomycin was obtained from Upjohn Ltd, Crawley, Sussex, and mitomycin C and other chemicals were obtained from Sigma Ltd, London.

Statistics. Analysis of variance and Student's $t$ test were used.

Assays of enterotoxic activity by the infant-rabbit method. The method was similar to that of Kutas et al. (1974). Infant rabbits (New Zealand White) were separated from their mothers shortly before use. Each animal was dosed orally by means of a polyethylene catheter, with the sample under test at the rate of $50 \mathrm{ml} / \mathrm{kg}$ body weight. The addition of $1 \mathrm{ml}$ of $5 \%$ Evans blue dye to each $100-\mathrm{ml}$ volume of test sample enabled the presence of the material in the stomach to be confirmed at necropsy. Unless otherwise stated, animals were killed $5 \mathrm{~h}$ after inoculation and their entire intestines removed. The ratio of gut weight to remaining body weight was calculated for each rabbit. Ratios below 0.070 were considered negative. In our hands rabbits inoculated with heated toxin preparations $\left(65^{\circ} \mathrm{C}\right.$ for $15 \mathrm{~min}$.) invariably gave ratios of $0.050-0.065$, with a mean coefficient of variance of $8 \%$. 
Assay of enterotoxic activity by the rabbit ligated-loop method. The method used was that of Evans, Evans and Pierce (1973a) with an 18-h incubation period. Adult New Zealand White rabbits were used with a maximum of 12 loops per rabbit. The inoculum volume was $2 \mathrm{ml}$ per loop and each sample was tested in at least four loops.

\section{RESULTS}

\section{Fermentation}

Various parameters monitored during the large-scale fermentation of $E$. coli strain P307 are shown in table I. The culture had reached the stationary phase after 12 hours' incubation, although there was a subsequent rise in the $p \mathrm{H}$ of the culture. There was no need to add antifoam during growth. The modified syncase medium was found to give consistently good growth and a high yield of LT.

TABLE I

Large-scale growth of E. coli strain P307 in modified syncase medium

\begin{tabular}{c|ccccc}
\hline $\begin{array}{c}\text { Age of } \\
\text { culture } \\
\text { (hours) }\end{array}$ & $\begin{array}{c}\text { pH } \\
\text { Optical density } \\
\text { at } 620 \mathrm{~nm} \text { pathlength }\end{array}$ & $\begin{array}{c}\text { \% } \\
\mathrm{CO}_{2}\end{array}$ & $\begin{array}{c}\text { Viable count } \\
\left(10^{9} \text { organisms }\right. \\
\text { per ml) }\end{array}$ & $\begin{array}{c}\text { Concentration } \\
\text { of glucose } \\
\text { (g/litre) }\end{array}$ \\
\hline 0 & 7.5 & 0.12 & 0.00 & 0.14 & N.3 \\
4 & 6.7 & 1.08 & 2.80 & ND & ND \\
12 & 7.9 & 1.84 & 0.15 & 8.82 & $<0.005$ \\
18 & 8.4 & 1.84 & $0 \cdot 10$ & 5.28 & ND \\
24 & 8.4 & 1.84 & 0.10 & 5.23 & $<0.005$ \\
\hline
\end{tabular}

$\mathrm{ND}=$ Not determined

\section{Study of the infant-rabbit model}

Numerous preliminary tests showed that rabbits aged 7-9 days were responsive to oral inoculation with cell lysate $(50 \mathrm{ml} / \mathrm{kg})$ produced from strain P307. Fluid accumulation was noted in the intestine, and gut weight to body weight $(\mathrm{GW} / \mathrm{BW})$ ratios in excess of 0.090 were routinely obtained. Heated cell lysates $\left(65^{\circ} \mathrm{C}\right.$ for $15 \mathrm{~min}$.) never produced $\mathrm{GW} / \mathrm{BW}$ ratios above 0.070 when inoculated into infant rabbits.

\section{Time course of response to $L T$}

Groups of rabbits aged 7-9 days were killed at various intervals after oral inoculation with P307 cell lysate $(50 \mathrm{ml} / \mathrm{kg})$. The time course of fluid accumulation is shown in fig. 1.

Fluid accumulation was evident $3 \mathrm{~h}$ after inoculation; maximum GW/BW ratios occurred 5-7 h after inoculation. A 5-h incubation time was subsequently used as a routine. 


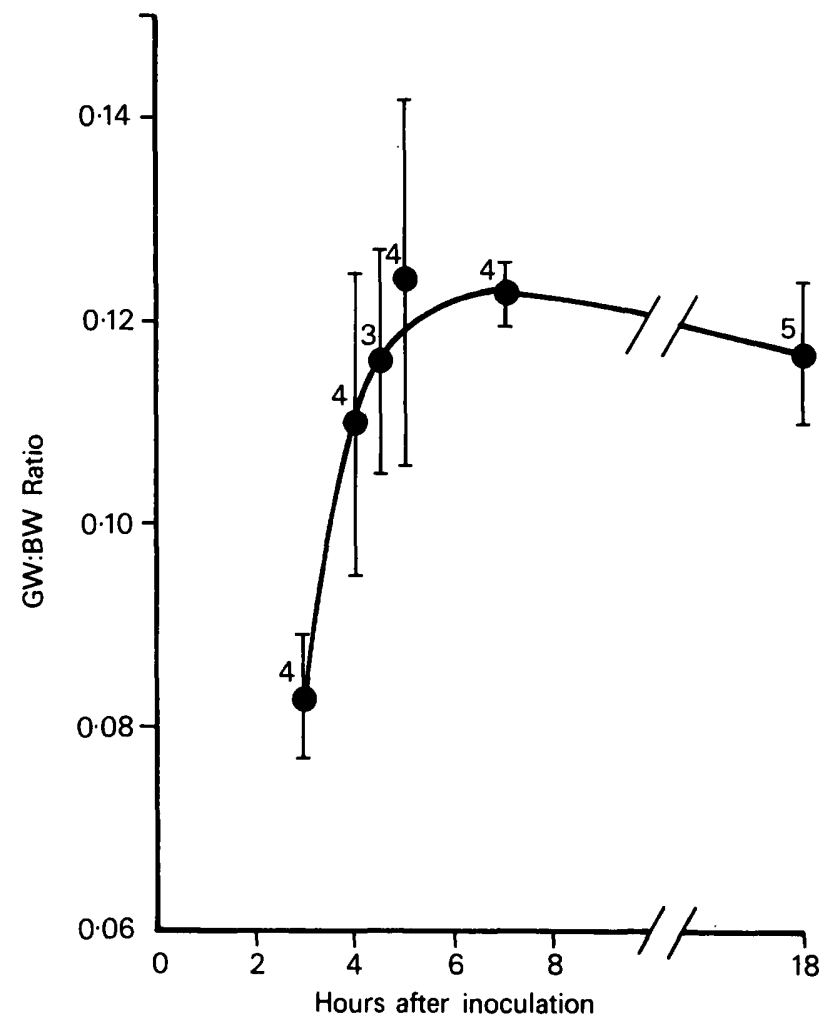

FIG. 1.-Time course of fluid accumulation in infant rabbits dosed orally with cell lysate of $E$. coli strain P307. Numbers next to symbols indicate the number of animals used to determine each point. Each point represents the mean ratio; the bars indicate the standard error of the mean (SEM). GW/BW ratio = ratio of gut weight to remaining body weight.

\section{Dose response}

A dose-related response was obtained with $\mathrm{P} 307$ cell lysate and is shown in fig. 2. Doses in excess of $30 \mathrm{ml} / \mathrm{kg}$ gave good positive responses.

\section{Effect of cell concentration on lysate activity}

Cell suspensions of $2.5,5.0$ and $25 \%$ wet weight/volume were used to prepare cell lysates, which were then assayed in infant rabbits at a dose of $50 \mathrm{ml} / \mathrm{kg}$. The results are shown in table II; the $5 \%$ cell suspension lysate was as active, if not more so, than the $25 \%$ cell suspension lysate.

\section{Age response}

Animals at 7, 10, 14 and 21 days of age were dosed at $50 \mathrm{ml} / \mathrm{kg}$ with P307 cell lysate and heated $\left(65^{\circ} \mathrm{C}\right.$ for $15 \mathrm{~min}$.) cell lysate. The results can be seen in fig. 3. The gastric $p \mathrm{H}$ of the animals dosed with unheated cell lysate was measured at necropsy and is also shown in fig. 3. 


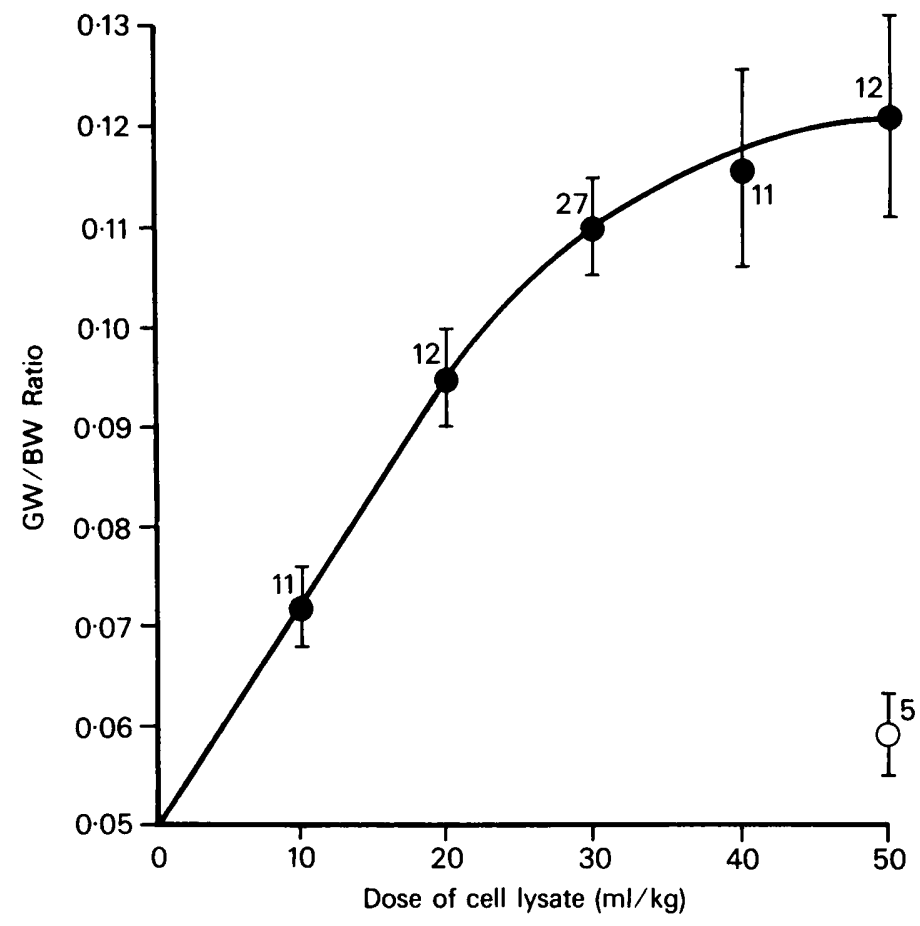

FIG. 2.-Dose response of infant rabbits to cell lysate of strain P307. $\bullet=$ Cell lysate; $o=$ heated cell lysate $\left(65^{\circ} \mathrm{C}\right.$ for $15 \mathrm{~min}$.). Numbers next to symbols indicate the number of animals used to determine each point. Each point represents the mean ratio; the bars indicate the SEM.

\section{TABLE II}

The toxicity for infant rabbits of lysates prepared from suspensions containing different concentrations of $E$. coli cells

\begin{tabular}{ccc}
$\begin{array}{c}\text { Concentration of } \\
\text { cell } \\
\text { suspension } \\
(\% \text { wet weight/volume) }\end{array}$ & $\begin{array}{c}\text { Number } \\
\text { of animals }\end{array}$ & $\begin{array}{c}\text { Gut weight to body weight } \\
\text { ratio }(\mathrm{GW} / \mathrm{BW}) \\
\text { of rabbits } 5 \mathrm{~h} \text { after dosing } \\
\text { (Mean } \pm \text { standard error } \\
\text { of mean }[\mathrm{SEM}])\end{array}$ \\
\hline $2 \cdot 5$ & 6 & $0.097 \pm 0.006$ \\
5 & 5 & $0 \cdot 133 \pm 0.013$ \\
25 & 4 & $0 \cdot 117 \pm 0.011$ \\
\hline
\end{tabular}

The animals remained responsive at 14 days of age, but became unresponsive by 21 days: the high control level at 21 days appeared to be due to increased faecal content. The gastric $p \mathrm{H}$ was 3.0 at 21 days of age; $p \mathrm{H}$ values of below 5.0 have previously been found to inactivate LT (Evans et al., 1973a).

\section{Effect of witholding food before dosing}

Rabbits were deprived of food for $18 \mathrm{~h}$ before they were dosed with P307 

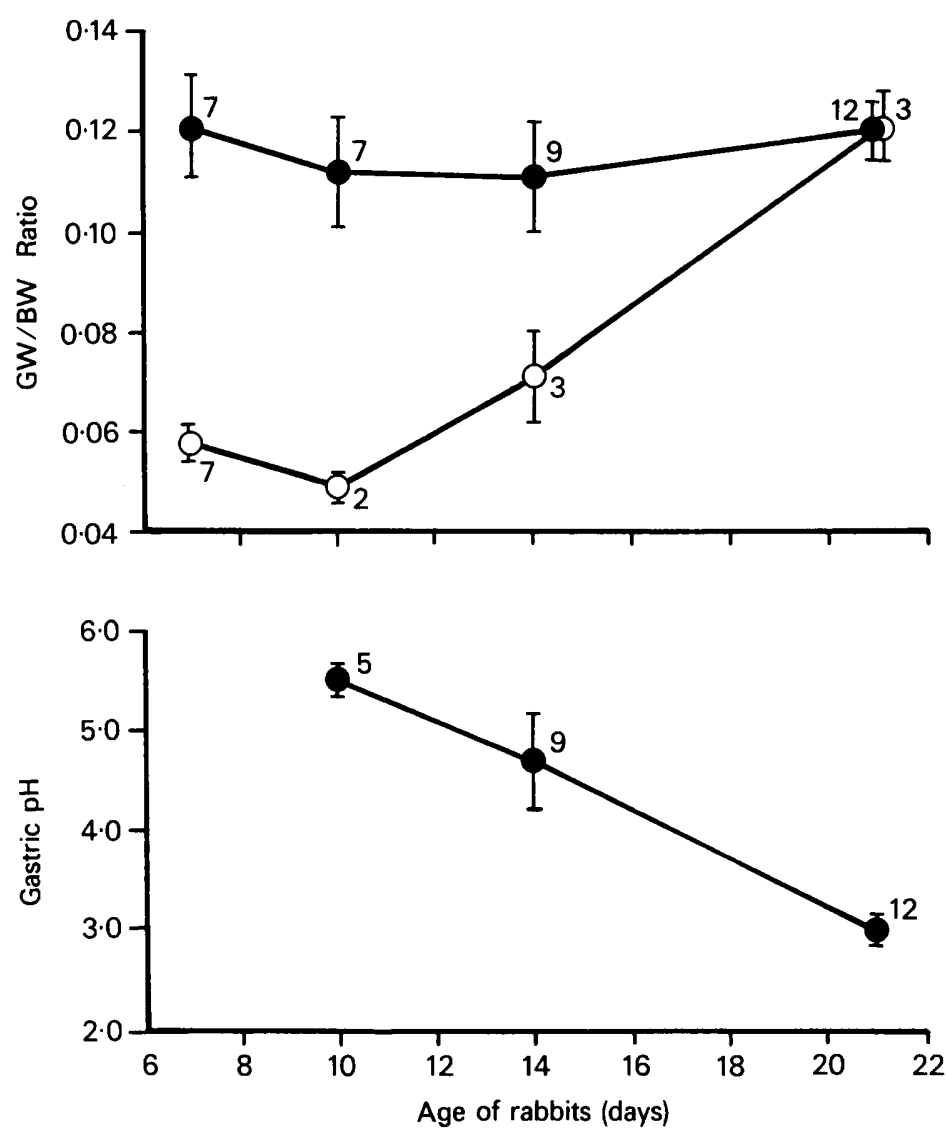

FIG. 3.-Effect of age on response of infant rabbits to cell lysate of strain P307, and gastric $p H$ at necropsy. $\bullet=$ Cell lysate; $O=$ heated cell lysate. Numbers next to symbols indicate the number of animals used to determine each point. Each point represents the mean ratio; the bars indicate the SEM.

\section{TABLE III}

Effect of witholding food before dosing with cell lysate

\begin{tabular}{|c|c|c|}
\hline \multirow{2}{*}{$\begin{array}{l}\text { Treatment of infant } \\
\text { rabbits before } \\
\text { dosing }\end{array}$} & \multicolumn{2}{|c|}{$\begin{array}{c}\text { Observations made on six } \\
\text { infant rabbits } 5 \mathrm{~h} \\
\text { after dosing } \\
\text { (means } \pm \text { SEM) }\end{array}$} \\
\hline & GW/BW ratio & Gastric $p \mathrm{H}$ \\
\hline $\begin{array}{l}\text { Food witheld for } 18 \mathrm{~h} \\
\text { Left with dam }\end{array}$ & $\begin{array}{l}0.071 \pm 0.009^{*} \\
0.104 \pm 0.005\end{array}$ & $\begin{array}{l}3.6 \pm 0 \cdot 1 \dagger \\
5 \cdot 5 \pm 0 \cdot 1\end{array}$ \\
\hline
\end{tabular}

* Significantly lower GW/BW ratio (p<0.025) than in untreated animals (Student's $t$ test).

$\dagger$ Significantly lower gastric $p \mathrm{H}(\mathrm{p}<0.001)$ than in untreated animals (Student's $t$ test). 
cell lysate. The gastric $p \mathrm{H}$ of the animals was measured at necropsy (table III). Fasting significantly reduced the response to LT and the final gastric $p \mathrm{H}$.

Stability of cell lysates during storage at $-20^{\circ} \mathrm{C}$

Two cell-lysate preparations were assayed weekly during storage at $-20^{\circ} \mathrm{C}$ for 7 weeks; the combined results are shown in fig. 4.

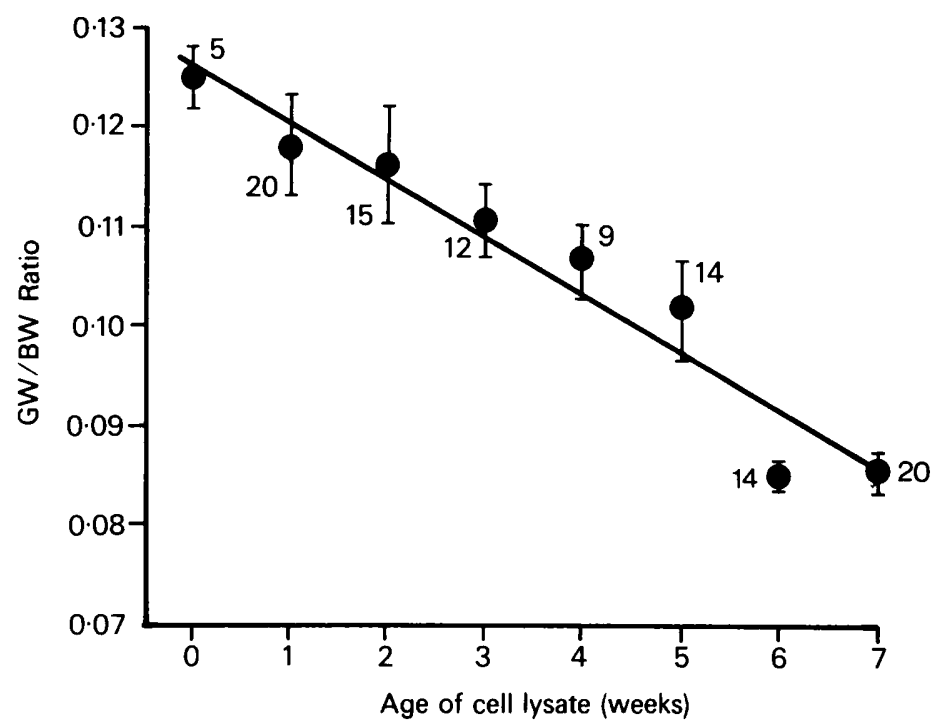

FIG. 4.-Stability of cell lysate of strain P307 at $-20^{\circ} \mathrm{C}$. Toxicity was tested in infant rabbits and numbers next to symbols indicate the number of animals used to determine each point. Each point represents the mean ratio; the bars indicate the SEM.

The line of best fit was then calculated by linear regression and is shown in fig. 4; the data gave a significant linear correlation $(p<0.001)$ indicating that crude LT was not stable when stored at $-20^{\circ} \mathrm{C}$. However, cells stored at $-20^{\circ} \mathrm{C}$ maintained their ability to produce active cell lysates for more than one year.

\section{Extracellular LT and cholera toxin}

Extracellular LT (m.w. > 50 000) and cholera enterotoxin were administed to infant rabbits (table IV). Crude cholera toxin was active at a dose of $25 \mathrm{mg} / \mathrm{kg}$ and the extracellular LT had comparable activity at a dose of $100 \mathrm{mg} / \mathrm{kg}$. Crude cholera toxin and extracellular LT were totally inactivated by heating at $65^{\circ} \mathrm{C}$ for $15 \mathrm{~min}$.

\section{Effect of lincomycin on LT yield}

Cell lysates from the five lincomycin-resistant substrains of $E$. coli pro- 
TABLE IV

Response of infant rabbits to extracellular LT and crude cholera toxin

\begin{tabular}{|c|c|c|c|}
\hline Treatment & $\underset{(\mathrm{mg} / \mathrm{kg})}{\text { Dose }}$ & $\begin{array}{c}\text { Mean GW/BW } \\
\text { ratio }( \pm \text { SEM) } \\
5 \text { h after dosing* }\end{array}$ & $\stackrel{\mathrm{p}}{\text { (Student's } t \text { ) }}$ \\
\hline $\begin{array}{l}\text { Cholera toxin } \\
\text { Inactivated cholera toxin } \\
\text { Extracellular LT } \\
\text { Inactivated extracellular LT }\end{array}$ & $\begin{array}{r}25 \\
200 \\
100 \\
100\end{array}$ & $\begin{array}{l}0.106 \pm 0.013(6) \\
0.055 \pm 0.002(4) \\
0.107 \pm 0.007(7) \\
0.056 \pm 0.003(6)\end{array}$ & $\begin{array}{l}<0.001 \\
<0.001\end{array}$ \\
\hline
\end{tabular}

* Numbers of animals in parenthesis

duced from strain P307 were assayed, together with the parent strain, in adult-rabbit ligated loops (table V). All five lincomycin-resistant strains gave higher titres of LT when grown in the presence of lincomycin. When compared with the parent strain, no significantly increased levels of LT were observed from any of the lincomycin-resistant strains, and three (B, C and E) gave significantly lower levels of LT than did the parent strain P307.

The two strains (A and D) that gave levels of LT comparable with those of the parent strain were assayed, together with the parent strain, at a 1 in 5 dilution. The results confirmed that elevation of LT titre had not occurred.

The biological activity of the cell lysates was invariably destroyed by heating at $65^{\circ} \mathrm{C}$ for $15 \mathrm{~min}$., confirming the heat-lability of the toxin.

TABLE V

Effect of lincomycin on the LT yield as assayed in ligated intestinal loops of adult rabbits

\begin{tabular}{|c|c|c|c|}
\hline $\begin{array}{c}\text { Strain } \\
\text { or sub-strain }\end{array}$ & $\begin{array}{l}\text { Concentration }(\mu \mathrm{g} / \mathrm{ml}) \text { of } \\
\text { lincomycin in growth } \\
\text { medium }\end{array}$ & $\begin{array}{l}\text { Mean volume/length } \\
\text { ratio ( } \pm \text { SEM }) \\
\text { of four loops }\end{array}$ & Significance $†(p)$ \\
\hline P307 & 0 & $1.49 \pm 0.13$ & $\cdots$ \\
\hline \multirow{2}{*}{$A^{*}$} & 0 & $0.73 \pm 0.29$ & $<0.01$ \\
\hline & $\mid 250$ & $1.46 \pm 0.11$ & NS \\
\hline \multirow{2}{*}{$\mathbf{B}^{*}$} & 0 & $0.05 \pm 0.03$ & $<0.001$ \\
\hline & 250 & $0.72 \pm 0.32$ & $<0.02$ \\
\hline \multirow{2}{*}{$\mathrm{C}^{*}$} & 0 & $0 \cdot 19 \pm 0.13$ & $<0.001$ \\
\hline & 250 & $0.50 \pm 0.30$ & $<0.01$ \\
\hline \multirow{2}{*}{$D^{*}$} & 0 & $0.44 \pm 0.22$ & $<0.001$ \\
\hline & 250 & $1.58 \pm 0.19$ & NS \\
\hline \multirow{2}{*}{$\mathrm{E}^{*}$} & 0 & 0 & $<0.001$ \\
\hline & 250 & $0.33 \pm 0.21$ & $<0.01$ \\
\hline
\end{tabular}

* Lin ${ }^{\mathrm{r}}$ isolate of strain P307

+ Significance (by analysis of variance) of result as compared with that of the parent strain P307.

NS $=$ Not significant. 


\section{Effect of MTC on LT toxin yield}

Cell lysates produced from strain P307 grown in the presence and absence of MTC $0.5 \mu \mathrm{g} / \mathrm{ml}$ were assayed in rabbit ligated loops (table VI). The biological activity of the samples was inactivated by heating at $65^{\circ} \mathrm{C}$ for $15 \mathrm{~min}$., confirming the heat-lability of the toxin.

The presence of MTC resulted in no increased toxin levels.

TABLE VI

\begin{tabular}{|c|c|c|}
\hline Strain & $\begin{array}{l}\text { Concentration }(\mu \mathrm{g} / \mathrm{ml}) \\
\text { of MTC in } \\
\text { growth medium }\end{array}$ & $\begin{array}{l}\text { Mean volume/length } \\
\text { ratio }( \pm \text { SEM }) \\
\text { of four loops }\end{array}$ \\
\hline \multirow[t]{2}{*}{ P307 } & None & $1.74 \pm 0.14$ \\
\hline & 0.5 & $1 \cdot 48 \pm 0 \cdot 15$ \\
\hline
\end{tabular}

\section{Extracellular $L T$}

The extracellular LT preparations were assayed in rabbit ligated loops and compared with a $5 \%$ cell-lysate sample (table VII). All the samples were inactivated by heating at $65^{\circ} \mathrm{C}$ for $15 \mathrm{~min}$., confirming the heat-lability of the toxin. Extracellular LT appeared to be heterogeneous, with a wide range of molecular weights. A dose-response curve for the material with m.w. of $>50000$ was obtained by the ligated-loop method and is shown in fig. 5. A dose of $20 \mathrm{mg} /$ loop had activity comparable with that of the $5 \%$ cell lysate.

TABLE VII

Assay of extracellular LT samples in ligated intestinal loops of adult rabbits

\begin{tabular}{c|cc}
\hline Sample & $\begin{array}{c}\text { Range of molecular } \\
\text { weights }\left(10^{3}\right)\end{array}$ & $\begin{array}{c}\text { Mean volume/length ratio } \\
( \pm \text { SEM }) \text { of four loops }\end{array}$ \\
\hline Cell lysate & $\ldots$ & $1 \cdot 81 \pm 0 \cdot 22$ \\
Extracellular LT & $5-10$ & $1 \cdot 38 \pm 0 \cdot 16$ \\
Extracellular LT & $10-50$ & $1.96 \pm 0.32$ \\
Extracellular LT & $>50$ & $1 \cdot 84 \pm 0.23$ \\
\hline
\end{tabular}

\section{Discussion}

Several sensitive tissue-culture techniques have been developed for the detection and quantitative assay of E. coli LT activity (Donta, Moon and Whipp, 1974; Guerrant et al., 1974; Kantor, Tao and Wisdom, 1974). However, we have been interested in studying the pathophysiological effect of LT and have therefore preferred to use the intact animal. To this end, we have 


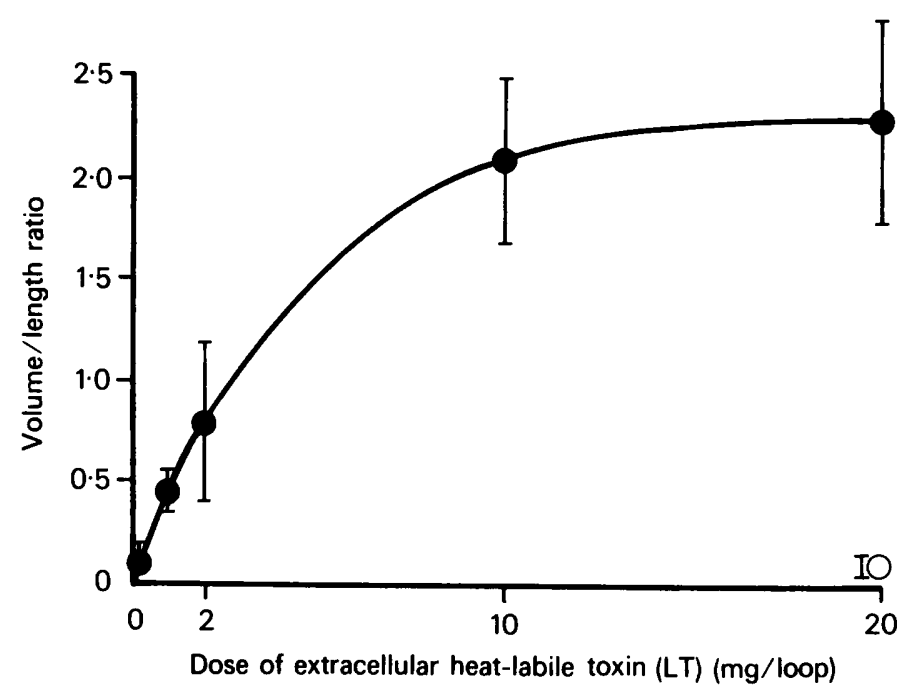

Fig. 5.-Dose response of ligated intestinal loops of adult rabbits to extracellular LT. $\bullet=$ Extracellular LT (m.w. $>50000)$; $\circ=$ heated extracellular $L T\left(65^{\circ} \mathrm{C}\right.$ for $15 \mathrm{~min}$.). Each point represents the mean ratio; the bars indicate the SEM of four loops.

studied the effect of oral administration of LT to infant rabbits, to avoid the of the standard rabbit-ileal loop system.

The dosing of infant rabbits with LT was first described by Smith (1972) and further investigated by Kutas et al. (1974). We have examined the response in more detail and have attempted to measure it by determining the ratios of gut weight to remaining body weight $(\mathrm{GW} / \mathrm{BW}) 5 \mathrm{~h}$ after the oral administration of LT. We hoped that this system might then be used to detect and quantify LT in a manner similar to that by which $E$. coli heat-stable enterotoxin (ST) can be detected and quantified in the infant mouse (Dean et al., 1972; Mullan, Burgess and Newsome, 1978).

The results show that $\mathrm{GW} / \mathrm{BW}$ ratios obtained from infant rabbits dosed with LT were invariably above 0.090 , whereas heat-inactivated LT always gave ratios below 0.070 . These ratios correspond to those found by means of the infant mouse assay for ST (Dean et al., 1972). In the infant mouse a near-maximal response occurs in $2 \mathrm{~h}$ (Mullan et al., 1978), but the response of infant rabbits to LT was much less rapid. Whilst fluid secretion was evident $3 \mathrm{~h}$ after inoculation, maximal $\mathrm{GW} / \mathrm{BW}$ ratios were not obtained until the 5 th hour. The infant rabbits were still responsive to LT at 14 days of age, but became unresponsive at 21 days. These findings correspond closely to those obtained in a study of mouse responsiveness to ST (Mullan et al., 1978). The failure of older rabbits to respond to LT may be associated with their gastric $p \mathrm{H}$, which is low enough to inactivate LT (Evans et al., 1973a).

LT is unstable when stored at $-20^{\circ} \mathrm{C}$, losing approximately half of its activity within 4 weeks. Similar findings have recently been reported by Mundell, Anselmo and Wishnow (1976). Both lincomycin (Levner et al., 1977) and mitomycin C (Isaacson and Moon, 1975) have previously been reported to 
increase the yield of LT from strains of $E$. coli. However, we were unable to confirm either claim from experiments with strain P307 in which the LT levels were measured by means of rabbit ligated-intestinal loops. Wadström, Möllby and Söderlind (1977), referring to a manuscript in preparation, noted that LT synthesis was apparently not increased by mitomycin C if intestinal loops were used for assay, but was dramatically increased if tissue culture was used for assay.

A possible explanation for this difference may be found in the different m.w. values reported for LT preparations; the values vary from 20000 (Evans et al., 1976) to >100 000 (Dorner, Jaksche and Stöckl, 1976) and this suggests a pronounced degree of heterogeneity. With our preparation of extracellular LT from E. coli $\mathrm{P} 307$, molecular weights ranging from $<10000$ to $>50000$ were noted.

Heating destroyed the activity of intracellular and extracellular LT and confirmed the absence of ST in the preparations used in this study.

\section{SUMMARY}

Infant rabbits were shown to respond to Escherichia coli heat-labile enterotoxin by a consistent increase in intestinal fluid content, which was maximal $5 \mathrm{~h}$ after oral dosing. Infant rabbits could be used in a simple quantitative assay for heat-labile $E$. coli enterotoxin based on the ratios of gut weight to remaining body weight $5 \mathrm{~h}$ after oral dosing. Infant rabbits remained responsive to heat-labile enterotoxin up to 14 days of age, after which their gastric $p \mathrm{H}$ became low enough to destroy the enterotoxin. Rabbits that had been deprived of food before being dosed had a reduced gastric $p \mathrm{H}$ and a reduced response to the enterotoxin.

Lincomycin and mitomycin $\mathrm{C}$ were found not to increase the yield of heat-labile enterotoxin from E. coli strain P307.

We thank Mr P. Whittington for excellent technial assistance, Dr D. Buckley for producing lincomycin-resistant strains of $E$. coli $\mathrm{P} 307$, and $\mathrm{Mr} \mathrm{A}$. Whittaker for the large-scale fermentation of E. coli strain P307.

\section{REFERENCES}

Dean, A. G., Ching, Y. C., Williams, R. G. And Harden, L. B. 1972. Test for Escherichia coli enterotoxin using infant mice: application in a study of diarrhea in children in Honolulu. $J$. infect. Dis., 125, 407.

Donta, S. T., Moon, H. W. AND WhIPP, S. C. 1974. Detection of heat-labile Escherichia coli enterotoxin with the use of adrenal cells in tissue culture. Science, N.Y., 183, 334.

DORNER, F., JAKSCHE, H. AND STÖCKL, W. 1976. Escherichia coli enterotoxin: purification, partial characterisation and immunological observations. J. infect. Dis., 133, suppl. S142.

Evans, D. G., Evans, D. J. AND PIERCE, N. F. 1973a. Differences in the response of rabbit small intestine to heat-labile and heat-stable enterotoxins of Escherichia coli. Infect. Immun.,7, 873.

Evans, D. J., Evans, D. G. AND Gorbach, S. L. 1973b. Production of vascular permeability factor by enterotoxigenic Escherichia coli isolated from man. Infect. Immun., 8, 725.

Evans, D. J., Evans, D. G., Richardson, S. H. and Gorbach, S. L. 1976. Purification of the 
polymyxin-released, heat-labile enterotoxin of Escherichia coli. J. infect. Dis., 133, suppl. S97.

Finkelstein, R. A., Norris, H. T. ANd DutTa, N. K. 1964. Pathogenesis of experimental in infant rabbits. 1. Observations on the intra-intestinal infection and experimental cholera produced with cell-free products. J. infect. Dis., 114, 203.

GuerRant, R. L., Brunton, L. L., Schnaitman, T. C., Rebhun, L. I. and Gilman, A. G. 1974. Cyclic adenosine monophosphate and alteration of Chinese hamster ovary cell morphology: a rapid, sensitive in vitro assay for the enterotoxins of Vibrio cholerae and Escherichia coli. Infect. Immun., 10, 320.

GyLes, C. L. AND BARNum, D. A. 1969. A heat-labile enterotoxin from strains of Escherichia coli enteropathogenic for pigs. J. infect. Dis., 120, 419.

ISAACSON, R. E. AND MOON, H. W. 1975. Induction of heat-labile enterotoxin synthesis in enterotoxigenic Escherichia coli by Mitomycin C. Infect. Immun., 12, 1271.

KANTOR, H. S., TAO, P. AND WISDOM, C. 1974. Action of Escherichia coli enterotoxin : adenylate cyclase behaviour of intestinal epithelial cells in culture. Infect. Immun., 9, 1003.

Kutas, F., Vetési, F. AND SEmún, G. 1974. Experimental diarrhoea in baby rabbits due to oral administration of heat-labile enterotoxin of $E$. coli enteropathogenic for swine. Acta vet. hung., 24, 177.

LeVNer, M., Wiener, F. P. AND Rubin, B. A. 1977. Induction of Escherichia coli and Vibrio cholerae enterotoxins by an inhibitor of protein synthesis. Infect. Immun., 15, 132.

Melling, J. AND Phillips, B. W. 1975. Large scale extraction and purification of enzymes. In Handbook of enzyme biotechnology, edited by A. Wiseman, Chichester, pp. 58-88.

Melling, J. AND SCOTT, G. K. 1972. Preparation of gram quantities of a purified R-factormediated penicillinase from Escherichia coli strain W3310. Biochem. J., 130, 55.

Mullan, N. A., Burgess, M. N. AND Newsome, P. M. 1978. Characterisation of a partially purified, methanol-soluble heat-stable Escherichia coli enterotoxin in infant mice. Infect. Immun., 19, 779.

Mundell, D., Anselmo, C. R. ANd Wishnow, R. M. 1976. Factors influencing heat-labile Escherichia coli enterotoxin activity. Infect. Immun., 14, 383.

SмITH, H. W. 1972. The production of diarrhoea in baby rabbits by the oral administration of cell-free preparations of enteropathogenic Escherichia coli and Vibrio cholerae: The effect of antisera. J. med. Microbiol., 5, 299.

Smith, H. W. AND Halls, S. $1967 a$. Observations by the ligated intestinal segment and oral inoculation methods on Escherichia coli infections in pigs, calves, lambs and rabbits. $J$. Path. Bact., 93, 449.

Smith, H. W. ANd Halls, S. 1967b. Studies on Escherichia coli enterotoxin. J. Path. Bact., 93, 531.

WADSTRÖM, T., MölLby, R. AND SöDERLIND, O. 1977. Heat-labile enterotoxins of Escherichia coli. Toxicon, 15, 511. 